\title{
PENGARUH PENGUNGKAPAN ESG TERHADAP KINERJA KEUANGAN PERUSAHAAN (STUDI EMPIRIS PADA PERUSAHAAN SEKTOR KEUANGAN YANG TERDAFTAR DI BEI PERIODE 2017-2019)
}

\author{
Era Vivianti Husada \\ Universitas NegeriSurabaya \\ eravivi.husada@gmail.com \\ Susi Handayani \\ Universitas NegeriSurabaya \\ susihandayani@unesa.ac.id
}

\begin{abstract}
This study aims to examine the effect of ESG disclosure on financial performance within firm. By using sample of 80 firms in finance sector, listed in Indonesia Stock Exchange for 2017-2019, sample selected using purposive sampling technique.Financial performance measured by Return on Asset, Tobin's Q, and Sales Growth, the analysis method used is multiple regression analysis. The result showed that ESG disclosure only affect Return on Asset simultaneously, furtheranalysis showed that none of the economic performance variables affected by ESG disclosure partially, instead control variable produce mixed result that affect financial performance variable itself.
\end{abstract}

Keywords: ESG, Financial Performance, Finance Sector

\begin{abstract}
ABSTRAK
Penelitian ini bertujuan untuk menguji pengaruh pengungkapan ESG terhadap kinerja keuangan dalam perusahaan. Dengan sampel sebanyak 80 perusahaan sektor keuangan yang terdaftar di Bursa Efek Indonesia tahun 2017-2019, sampel dipilih dengan menggunakan teknik purposive sampling. Kinerja keuangan diproksikan dengan Return on Asset, Tobin's Q, dan Sales Growth, metode analisis yang digunakan adalah analisis regresi berganda. Hasil penelitian menunjukkan bahwa pengungkapan ESG hanya berpengaruh terhadap Return on Asset secara simultan, analisis lebih lanjut menunjukkan bahwa tidak ada satu pun variabel kinerja ekonomi yang dipengaruhi oleh pengungkapan ESG secara parsial, sebaliknya variabel kontrol menghasilkan hasil yang beragam yang mempengaruhi variabel kinerja keuangan itu sendiri.
\end{abstract}

Kata Kunci: ESG, Kinerja Keuangan, Sektor Keuangan 


\section{PENDAHULUAN}

Sistem industri global telah memasuki industri 5.0, industri 5.0 adalah sistem industri yang berfokus pada sinergi antara manusia dan mesin otomatis atau teknologi (Nahavandi, 2019). Kondisi ini ditandai dengan keadaan industri global yang terus berkembang, membuat proses bisnis perusahaan juga berkembang. Kemajuan ekonomi ini juga diiringi kemunduran aspek lingkungan, salah satunya yaitu rusaknya hutan. Menurut statistik lingkungan hidup Indonesia (2019), menunjukkan bahwa luas lahan berhutan di Indonesia mengalami tren penurunan sejak 2013 hingga 2018, dengan rata-rata penurunan luas per tahun sebesar 740.000 hektare.

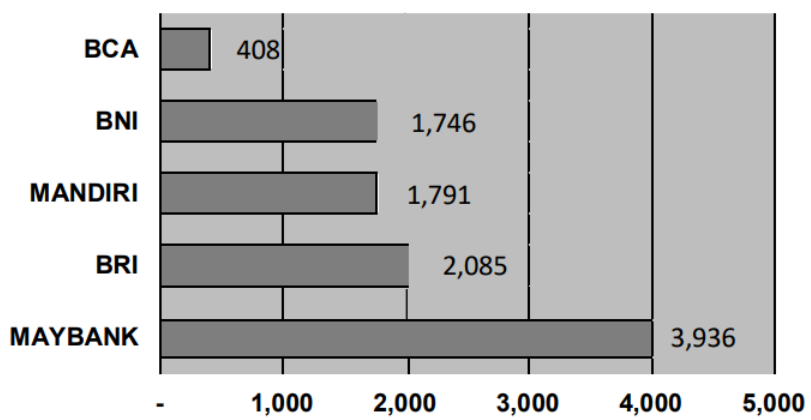

Sumber: Tinjauan Reformasi Keuangan Berkelanjutan Indonesia (2019)

Deforesitation sebagian besar diakibatkan oleh alih fungsi lahan hutan menjadi perkebunan sawit, terlebih lagi Indonesia menyumbang $53 \%$ budi daya kelapa sawit di dunia (Central Bureau of Statistics, 2019). Sektor industri berisiko tinggi tersebut dapat beroperasi karena adanya pendanaan yang berasal dari lembaga jasa keuangan. Sehingga secara tidak langsung lembaga jasa keuangan seperti bank juga turut berperan mendukung terjadinya kerusakan lingkungan. Berdasarkan data dari Tinjauan Reformasi Keuangan Berkelanjutan Indonesia (2019), mengungkapkan bahwa terdapat lima bank terbesar Indonesia yang turut andil dalam pendanaan perusahaan perusahaan yang merisikokan hutan. Seperti yang digambarkan dalam Gambar 1, total dana yang telah disalurkan dari kelima bank tersebut sejak tahun 2015 hingga 2019 adalah sebesar USD 9.966 juta. Gambar 1. Akumulasi Kredit Bank Merisikokan Hutan Tahun 2015-2019 (USD Juta). Untuk merespon fenomena ini pemerintah Indonesia telah bergerak untuk mendukung perusahaan dalam mengimplementasikan laporan keberlanjutan. Melalui OJK, telah dikeluarkan Peraturan Otoritas Jasa 
Keuangan Nomor $51 \quad$ /POJK.03/2017

Tentang Penerapan Keuangan Berkelanjutan Bagi Lembaga Jasa Keuangan, Emiten, Dan Perusahaan Publik. Tujuan diterapkannya laporan keuangan yang berkelanjutan adalah untuk menjaga stabilitas dan inklusifitas perekonominan, dengan menciptakan sinergi antara aspek ekonomi, sosial, dan lingkungan hidup. Berdasarkan survey dari KPMG CSR Survey (2017), dengan menggunakan Global Reporting Initiative (GRI) reporting framework. Terdapat peningkatan nilai pengungkapan laporan keuangan keberlanjutan sebesar $41,5 \%$ sejak tahun 2008, dengan persentase sebesar 53\%di tahun 2008 dan $75 \%$ ditahun 2018. Ini menunjukkan semakin banyak perusahaan yang sadar betapa pentingnya peran perusahaan dalam menjaga aspek sosial dan lingkungan, untuk tetap mendapatkan kepercayaan dari masyarakat. Saat ini laporan keuangan dianggap belum mencukupi kebutuhan pemegang saham, laporan tambahan lainnya juga dibutuhkan seperti, laporan intelektual dan laporan keberlanjutan (Wulf, Niemoller, \& Rentzsch, 2014). Laporan keberlanjutan menyajikan informasi non keuangan perusahaan, yang menjelaskan tentang aspek ekonomi, lingkungan, dan sosial perusahaan, tiga komponen laporan keberelanjutan antara lain lingkungan, sosial, dan tata kelola atau ESG (Buallay, 2019b). Pengungkapan ESG dapat memberikan keuntungan bagi perusahaan dan stakeholder. Laporan keberlanjutan akan mengarah pada pengambilan keputusan yang baik, transparansi, dan stabilitas keuangan yang berkelanjutan (Eccles, Krzus, \& Ribot, 2015). Berdasarkan penelitian terdahulu mengenai pengungkapan ESG dalam laporan keuangan terhadap kinerja perusahaan, salah satunya adalah penelitian dari (FerreroFerrero, Izqueirdo-Fernandez, M, \& MunozTorres, 2016), yang menguji pengaruh praktik ESG terhadap kinerja ekonomi. Penelitian tersebut menunjukkan hasil positif antara praktik ESG dan kinerja ekonomi, perusahaan yang memiliki interdimensional consistency, menunjukkan praktik ESG dan kinerja ekonomi yang lebih baik dari pada perusahaan lainnya. Hasil positif ini juga ditunjukkan dari hasil penelitian yang dilakukan oleh (Cornett, Erhemjamts, \& Tehranian, 2016), (Shakil, Mahmood, Tasnia, \& Munim, 2019), dan (Yawika \& Handayani, 2019) dengan hasil penelitian bahwa ESG berpengaruh positif terhadap kinerja keuangan. Penelitian terdahulu juga dilakukan oleh (Climent, 2018), yang menguji pengaruh ESG terhadap kinerja keuangan Return on Asset dan Return on Equity, yang menunjukkan hasil negatif. 
Pengaruh Pengungkapan ESG Terhadap Kinerja Keuangan Perusahaan

(Studi Empiris Pada Perusahaan Sektor Keuangan Yang Terdaftar Di BEI Periode 2017-2019)

Hasil negatif diperoleh karena perusahaan yang menjalankan ethical practice, memiliki biaya yang lebih besar untuk membiayai proyek sosial, sehingga mengorbankan return perusahaan. Hasil yang sama juga ditunjukkan oleh penelitian dari (Buallay, 2019a), (Maama, 2020), dan (Nollet, Filis, \& Mitrokostas, 2016). Dengan hasil penelitian ESG yang tidak signifikan dan atau negatif, terhadap Return on Asset, Return on equity, dan Tobin's $Q$. Dari beberapa hasil penelitian yang telah dijelaskan di atas, maka pelaku usaha khususnya di sektor keuangan

\section{TELAAH LITERATUR}

\section{Legitimacy Theory}

Legitimacy theory menyatakan organisasi perlu mempertimbangkan perilaku dan keputusan yang diambil sehubungan dengan lingkungannya (Dowling \& Pfeffer, 1975). Statement ini juga didukung (Braam, L, Hauck, \& Huijbregts, 2016), yang

\section{Stakeholder Theory}

Stakeholder theory menyatakan, bahwa organisasi berusaha meningkatkan profit dan nilai perusahaan untuk merespon ekspektasi stakeholder, dengan mengidentifikasi, diharapkan untuk tidak hanya fokus terhadap aspek laba, namun juga dapat mengintegrasikan aspek lingkungan, sosial, dan tata kelola terhadap proses bisnis, yang dituangkan dalam pengungkapan laporan keberlanjutan untuk mengimplementaskan praktik bisnis yang bertanggung jawab dan berkelanjutan. Maka penelitian ini dilakukan untuk menguji pengungkapan ESG terhadap kinerja keuangan perusahaan sektor keuangan dengan menggunakan instrumen Global Reporting Initiative.

menyatakan ketika perusahaan tidak bisa memenuhi ekspektasi publik, maka perusahaan berpotensi mengalami tekanan publik yang berakibat munculnya celah legitimasi.

menilai, dan mengevaluasi stakeholder yang memberikan dampak dan atau stakeholder yang terdampak aktivitas bisnis perusahaan (Freeman \& McVea, 1984). 


\section{Agency Theory}

Agency theory menyatakan, bahwa agen bertindak pihak lain atau prinsipal dalam sebuah organisasi (Mitnick, 1975). Agency theory menyampaikan argumen bahwa tugas manajemen adalah untuk memaksimalkan laba bagi shareholder. Sehingga dengan

\section{Pengungkapan ESG}

Sebelumnya tujuan utama perusahaan hanya pada profit, namun saat ini perusahaan mencoba untuk lebih memperhatikan parktik

\section{Kinerja Keuangan}

Kinerja keuangan adalah indikator pencapaian positif perusahaan dalam periode tertentu. Tujuan dari pengukuran kinerja perusahaan adalah untuk mendapatkan informasi yang berkaitan dengan efisiensi penggunaan dana, yang dapat membantu

\section{Pengembangan Hipotesis}

\section{Pengaruh pengungkapan ESG terhadap}

\section{Return on Asset}

Perusahaan yang memiliki interdimensional menunjukkan praktik ESG dan kinerja ekonomi yang lebih baik dari pada perusahaan lainnya (Ferrero-Ferrero, Izqueirdo-Fernandez, M, \& Munoz-Torres, 2016). Pernyataan ini didukung dengan hasil penelitian (Buallay, 2019b) dan (Shakil, Mahmood, Tasnia, \& Munim, 2019), bahwa biaya investasi terhadap praktik tanggung jawab sosial yang lebih besar dari pada maksimalisasi nilai perusahaan, dan membebankan pengeluaran atas investasi kepada shareholder.

ESG untuk mencapai keberlanjutan (Kocmanova, Docekalova, Nemecek, \& Simberova, 2011).

manajemen untuk membuat keputusan optimal bagi perusahaan (Almajali, Alamro, \& Al-Soub, 2012). Pada penelitian ini kinerja keuangan diproksikan oleh Return on Asset, Tobin.s Q, dan Sales Growth.

terdapat pengaruh positif antara pengungkapan ESG dan kinerja keuangan perusahaan khususnya Return on Asset consistency ini menunjukkan bahwa investasi pengungkapan ESG memiliki biaya lebih rendah, serta investor memiliki harapan dan tertarik dengan pengungkapan ESG yang dilakukan perusahaan (Buallay, 2019b). 
sebagai berikut:

$$
\begin{array}{ll}
\text { H1: } & \text { Pengungkapan ESG } \\
& \text { berpengaruh positif terhadap } \\
& \text { Return on Asset }
\end{array}
$$

\section{Pengaruh Pengungkapan ESG terhadap}

\section{Tobin's Q}

Saat perusahaan mulai berkomitmen untuk melakukan pengungkapan ESG, perusahaan telah berkontribusi dalam peningkatan lingkungan dan sosial secara regional dan atau global (Mgbame, Aderin, Ohalehi, \& Chijoke-Mgbame, 2020). Hasil penelitian

\section{Pengaruh pengungkapan ESG terhadap}

\section{Sales Growth}

Bagi perusahaan pertumbuhan penjualan merupakan salah satu indikator penting untuk mengukur pencapaian perusahaan, (Romi, Cook, \& Dixon-Fowler, 2018) meneliti tentang perbandingan perusahaan yang peduli atas aktivitas sosial dan tidak, hasil penelitian bahwa perusahaan melaksanakan aktivitas sosial memiliki sales dari (Aboud \& Diab, 2018), (Fatemi, Glaum, \& Kaiser, 2018), (Plumlee, Brown, Hayes, \& Marshall, 2015), dan (Yoon, Lee, \& Byun, 2018). Sehingga dapat dirumuskan hipotesis (H2) sebagai berikut:

H2: Pengungkapan ESG berpengaruh positif terhadap Tobin's $Q$

growth yang lebih baik, hasil yang sama diperoleh (Nyame-Asiamah \& Ghulam, 2019); (Romi, Cook, \& Dixon-Fowler, 2018) juga mengungkapkan, bahwa terdapat pengaruh positif antara pengungkapan informasi mengenai aktivitas lingkungan terhadap nilai perusahaan. Sehingga dapat dirumuskan hipotesis (H3) sebagai berikut:

\section{H3: Pengungkapan ESG}

berpengaruh positif terhadap Sales Growth 


\section{METODOLOGI PENELITIAN}

Jenis penelitian ini merupakan penelitian kuantitatif, dan jenis data dalam penelitian ini menggunakan data sekunder. Populasi yang digunakan adalah perusahaan yang terdapat dalam sektor keuangan, pada Bursa Efek

\section{Pengungkapan ESG}

Menurut (Whitelock, 2015) ESG adalah aktivitas perusahaan yang berhubungan dengan ekologi disekitarnya, interaksi dengan lingkungan sosial, dan sistem
Indonesia dari tahun 2017 hingga 2019. Teknik sampling yang digunakan dalam memilih sampel pada penelitian ini adalah purposive sampling. Total perusahaan sampel sebesar 80 perusahaan.

pengendalian internal perusahaan dengan tujuan untuk mencapai tujuan perusahaan dan memenuhi kebutuhan stakeholder. Indeks ESG dihitung dengan rumus:

$$
\begin{aligned}
& \text { Indeks ESG } \\
& =\frac{\text { Nilai Pengungkapan ESG }}{\text { Total Pengungkapan Maksimal }} \times 100 \%
\end{aligned}
$$

\section{Return on Asset}

Return on Asset adalah instrumen yang umum digunakan untuk mengukur profit yang diperoleh perusahaan, selain itu rasio return on asset (Masood \& Ashraf, 2012).
Return on Asset dihitung dengan rumus (Buallay, Fadel, Alajmi, \& Saudagaran, 2020):

$$
\text { Return on Asset }=\frac{\text { Laba Bersih }}{\text { Total Aset }}
$$

\section{Tobin's Q}

Tobin's $Q$ merupakan instrumen yang Tobin's $Q$ dihitung dengan rumus (Melinda digunakan untuk mengukur nilai sebuah \& Wardhani, 2020):

Nilai Pasar Ekuitas + Total Liabilitas

Nilai Buku Aset 


\section{Sales Growth}

Merupakan salah satu indikator penting sebuah industri (Ameer \& Othman, 2012). dalam pengukuran kinerja perusahaan. Sales Sales Growth dihitung dengan rumus (Harsh growth dapat mendefinisikan kompetitifnya \& Kumar, 2017):

$$
\begin{aligned}
& \text { Sales Growth } \\
& =\frac{\text { Penjualan } t 1-\text { Penjualan } t 0}{\text { Penjualan } 0}
\end{aligned}
$$

\section{Ukuran Perusahaan}

Ukuran perusahaan diukur dengan Ukuran perusahaan dihitung dengan rumus indikator seperti penjualan, modal, dan (Braam, L, Hauck, \& Huijbregts, 2016): total aset (Nawangsari \& Iswajuni, 2019).

$$
\text { Ukuran Perusahaan }=\operatorname{Ln}(\text { Total Aset })
$$

\section{Leverage}

Leverage adalah rasio yang (Ahmad, Salman, \& Shamsi, 2015). membandingkan antara utang dan aset, Leverage dihitung dengan rumus (Aboud \& leverage menginformasikan struktur modal Diab, 2018):

perusahaan yang berasal dari pinjaman

$$
\text { Leverage }=\frac{\text { Total Kewajiban }}{\text { Total Aset }}
$$

\section{Model Regresi}

Pada penelitian ini pengujian hipotesis dilakukan menggunakan analisis regresi linier berganda, analisis regresi linier berganda berfungsi untuk mengetahui pengaruh dan arah hubungan antara variabel x dan variabel y (Ghozali, 2016). Model yang digunakan untuk menguji hipotesis adalah:

$$
\begin{aligned}
& \text { FP (ROA, Tobin's Q, Sales Growth) }= \\
& \alpha_{0}+\beta_{1} E N V+\beta_{2} S O S+\beta_{3} C G V+\beta_{4} S Z E+\beta_{5} L E V+\varepsilon_{i t}
\end{aligned}
$$


Keterangan:

$\begin{array}{llll}\text { EP } & : \text { Economicperformance } & \text { CGV } & : \text { Tata Kelola } \\ \alpha & : \text { Konstanta } & \text { SZE } & : \text { Ukuran perusahaan } \\ \beta & : \text { Koefisien regresi } & \text { LEV } & : \text { Leverage } \\ \text { ENV } & : \text { Lingkungan } & \varepsilon_{i t} & : \text { Tingkat eror } \\ \text { SOC } & : \text { Sosial } & & \end{array}$

\section{HASIL DAN PEMBAHASAN}

Berdasarkan tabel 1 menunjukkan ketiga lebih besar dari signifikan acuan yaitu 0,05 model regresi sudah memenuhi asumsi $(\alpha=5 \%)$

normalitas ditandai dengan tingkat signifikan

\section{Uji Asumsi Klasik}

\section{Tabel 1 Hail Uji Asumsi Klasik}

Selanjutnya dalam uji auto korelasi nilai $\mathrm{du}<\mathrm{dw}<4$-du,dengan nilai dl sebesar 1,8312, Durbin Watson untuk ketiga model regresi dan nilai 4-du 2,1689.

berada ditengah-tengah dl dan 4-du atau

Variabel Dependen

\begin{tabular}{|c|c|c|c|c|c|c|c|c|c|}
\hline \multirow{3}{*}{$\begin{array}{l}\text { Variabel } \\
\text { Independen }\end{array}$} & \multicolumn{9}{|c|}{ Variabel Dependen } \\
\hline & \multicolumn{3}{|c|}{$R O A$} & \multicolumn{3}{|c|}{ Tobin's $Q$} & \multicolumn{3}{|c|}{ Sales Growth } \\
\hline & Tolerance & VIF & Sig. & Tolerance & VIF & Sig. & Tolerance & VIF & Sig. \\
\hline X1_Lingkungan & 0,420 & 2,381 & 0,978 & 0,420 & 2,381 & 0,401 & 0,381 & 2,622 & 0,982 \\
\hline X2_Sosial & 0,623 & 1,604 & 0,099 & 0,623 & 1,604 & 0,623 & 0,601 & 1,663 & 0,342 \\
\hline X3_Tata Kelola & 0,579 & 1,726 & 0,917 & 0,579 & 1,726 & 0,715 & 0,419 & 2,385 & 0,192 \\
\hline $\begin{array}{l}\text { Z1_Ukuran } \\
\text { Perusahaaan }\end{array}$ & 0,567 & 1,763 & 0,118 & 0,567 & 1,763 & 0,245 & 0,646 & 1,547 & 0,559 \\
\hline Z2_Leverage & 0,841 & 1,189 & 0,676 & 0,841 & 1,189 & 0,798 & 0,826 & 1,211 & 0,545 \\
\hline Sig. & & & 0,200 & & & 0,086 & & & 0,200 \\
\hline Durbin-Watson & & & 1,847 & & & 1,935 & & & 1,938 \\
\hline
\end{tabular}

Sumber: Output SPSS

Sehingga ketiga model regresi telah terbebas dari gejala autokorelasi. Pada uji multikolinearitas setiap variabel memiliki nilai Variance Infliator Factor (VIF) kurang dari 10. Selain itu, nilai Tolerance dari seluruh variabel memiliki nilai lebih dari0,10, sehingga model regresi dalam penelitian ini tidak mengandung gejala multikolinearitas. Yang terakhir yaitu uji heteroskedastisitas,dengan tingkat signifikan 
Pengaruh Pengungkapan ESG Terhadap Kinerja Keuangan Perusahaan

(Studi Empiris Pada Perusahaan Sektor Keuangan Yang Terdaftar Di BEI Periode 2017-2019)

menunjukkan nilai diatas $0,05(\alpha=5 \%)$ terbebas dari heterokedastisitas.

Sehingga ketiga model regresi dinyatakan

\section{Koefisien Determinasi $\left(\mathbf{R}^{2}\right)$}

\section{Tabel 2 Koefisien Determinasi Simultan}

$\left(\mathbf{R}^{2}\right)$ Model Summary.

\begin{tabular}{|c|c|c|c|}
\hline Model & R Square & Adjusted R Square & Std. Error of the Estimate \\
\hline 1 & 0,649 & 0,565 & 0,51377 \\
2 & 0,247 & 0,068 & 0,11636 \\
3 & 0,392 & 0,158 & 0,66012 \\
\hline
\end{tabular}

1 Dependent variable: Y1_Return on Asset; 2Y2_Tobin's Q; $3 Y 3$ Sales Growth Predictors: (Constant),X1_Lingkungan, X2_Sosial, X3_Tata Kelola, Z1_Ukuran Perusahaan, Z2_Leverage

Sumber: Output SPSS

Pada tabel 2 model regresi 1 memiliki nilai Adjusted $R$ Square sebesar 0,565 atau $56,5 \%$. Artinya sebesar 56,5\% variasi pada variabel dependen (Return on Asset) yang dapat dijelaskan oleh variabel independen dan variabel kontrol, sedangkan sisanya sebesar 43,5\% dijelaskan oleh variabel lain diluar model regresi. Untuk nilai Adjusted $R$ Square pada model regresi 2 adalah sebesar 0,068, yang berarti sebanyak 6,8\% variasi pada variabel dependen (Tobin's $Q$ ) yang dapat dijelaskan oleh variabel independen dan variabel kontrol, sedangkan sisanya sebesar 93,2\% dijelaskan oleh variabel lain diluar model regresi. Nilai AdjustedR Square untuk model regresi ketiga adalah sebesar 0,158 , artinya sebanyak $15,8 \%$ variasi pada variabel dependen (Sales Growth) yang dapat dijelaskan oleh variabel independen dan variabel kontrol, sedangkan sisanya sebesar $84,2 \%$ dijelaskan oleh variabel lain diluar model regresi. 


\section{Uji Statistik F}

\begin{tabular}{llll}
\hline Model & F & Sig. \\
\hline 1 & Regression & 7,762 & $0,000^{\mathrm{b}}$ \\
& Residual & & \\
& Total & & \\
2 & Regression & 1,379 & $0,272^{\mathrm{b}}$ \\
& Residual & & \\
& Total & & \\
3 & Regression & 1,677 & $0,209^{\mathrm{b}}$ \\
& Residual & & \\
& Total & & \\
\hline
\end{tabular}

Sumber: Output SPSS

Pada tabel 3 menunjukkan model regresi 1 memiliki signifikan 0,000 atau dibawah tingkat signifikan 0,05 . Sehingga H1 diterima, bahwa variabel independen dan variabel kontrol secara simultan berpengaruh terhadap variabel denpenden Y1 (Return on Asset). Untuk model regresi 2 memiliki nilai signifikan 0,272 atau diatas tingkat signifikan 0,05 . Sehingga $\mathrm{H} 2$ ditolak, bahwa variabel independen dan variabel kontrol secara simultan tidak berpengaruh terhadap variabel denpenden Y2 (Tobin's $Q$ ). Model regresi 3 memiliki nilai signifikan 0,209 atau diatas tingkat signifikan 0,05 . Sehingga $\mathrm{H} 3$ ditolak, bahwa variabel independen dan variabel kontrol secara simultan tidak berpengaruh terhadap variabel denpenden Y3 (Sales Growth). 


\section{Uji Statistik T}

Tabel 4 Uji Signifikansi Parsial

Coefficients $^{\mathrm{a}}$

\begin{tabular}{|c|c|c|c|}
\hline \multirow{2}{*}{$\begin{array}{c}\text { Variabel Independen/ } \\
\text { Kontrol }\end{array}$} & \multicolumn{3}{|c|}{ Variabel Dependen } \\
\hline & $\begin{array}{l}\text { ROA } \\
\text { Sig. }\end{array}$ & $\begin{array}{l}\text { Tobin's } Q \\
\text { Sig. }\end{array}$ & $\begin{array}{l}\text { Sales Growth } \\
\text { Sig. }\end{array}$ \\
\hline (Constant) & 0,000 & 0,110 & 0,024 \\
\hline X1_Lingkungan & 0,817 & 0,155 & 0,054 \\
\hline X2_Sosial & 0,637 & 0,942 & 0,943 \\
\hline X3_Tata Kelola & 0,128 & 0,892 & 0,196 \\
\hline Z1_Ukuran Perusahaan & 0,002 & 0,088 & 0,023 \\
\hline Z2_Leverage & 0,023 & 0,097 & 0,582 \\
\hline
\end{tabular}

1 Dependent Variable: Y1_Return on Asset

2 Dependent variable: Y2_Tobin's $Q$

3 Dependent variable: Y3_Sales Growth

Sumber: Output SPSS

Berdasarkan hasil uji signifikansi parsial pada tabel 4, dalam model regresi 1 variabel X1 Lingkungan memiliki signifikan 0,817, lebih tinggi dari pada tingkat signifikan yang telah ditentukan, yaitu 0,05. Sehingga variabel Pengungkapan Lingkungan secara parsial tidak berpengaruh terhadap variabel dependen Y1 Return on Asset. Selanjutnya variabel Pengungkapan Sosial memiliki signifikan 0,637, lebih tinggi dari pada tingkat signifikan yang telah ditentukan, yaitu 0,05. Sehingga H1b ditolak bahwa variabel independen X2 Sosial secara parsial tidak berpengaruh terhadap Variabel dependen Y1 Return on Asset. Kemudian variabel X3 Tata Kelola memiliki signifikan 0,128, lebih tinggi dari pada tingkat signifikan yang telah ditentukan, yaitu 0,05. Sehingga variabel pengungkapan Tata Kelola secara parsial tidak berpengaruh terhadap variabel dependen Y1 Return on Asset. Pada pengujian variabel kontrol Z1 Ukuran Perusahaan dan Z2 Leverage, memiliki tingkat signifikan 0,023 memiliki 
signifikan 0,002 , lebih rendah dari pada tingkat signifikan yang telah ditentukan, yaitu 0,05. Sehingga variabel Z1 Ukuran Perusahaan dan Z2 Leverage secara parsial berpengaruh terhadap variabel dependen Y1

\section{Pengaruh ESG Terhadap Return on Asset}

Model regresi 1 menunjukkan pengungkapan lingkungan tidak berpengaruh terhadap

Return on Asset. Hasil ini terjadi dengan alasan, bahwa investor pada sektor keuangan belum mempertimbangkan praktik dan pengungkapan lingkungan sebagai salah satu faktor yang menentukan keputusan investasi pada sebuah perusahaan (Buallay, 2019b). Sehingga dalam hasil penelitian ini, pengungkapan bukanlah faktor yang mempengaruhi Return on Asset. Selain itu sebagian besar perusahaan sampel belum menerapkan pengungkapan lingkungan dengan layak. Pernyataan ini dibuktikan dengan dari total 80 perusahaan sampel dengannilai rata- rata sebesar 0,560 , sebanyak 71 perusahaan memiliki nilai pengungkapan lingkungan dibawah ratarata. Sejalan dengan Agency Theory yang mengungkapkan bahwa agen dan pemilik memiliki tujuan yang berbeda, agen bertindak untuk personal benefit berupa reputasi sedangkan laba adalah tujuan pemilik. Sehingga perusahaan berusaha
Return on Asset.yang telah ditentukan, yaitu 0,05 . Sehingga variabel Z1 Ukuran Perusahaan dan Z2 Leverage secara parsial berpengaruh terhadap variabel dependen Y1 Return on Asset.

meminimalkan pengeluaran yang berhubungan dengan praktik terhadap lingkungan, dan dialihkan untuk memaksimalkan laba bagi pemilik. Pengungkapan sosial juga tidak berpengaruh terhadap Return on Asset. Kondisi ini terjadi karena praktik sosial hanya akan memberikan hasil saat investasi pada tingkat tertentu dan atau pencapaian dalam praktik sosial telah dibuat, sehingga sebelum perusahaan berada dalam titik tersebut, pengeluaran apapun dalam praktik sosial tidak akan berpengaruh terhadap kinerja keuangan (Nollet, Filis, \& Mitrokostas, 2016). Sama halnya kedua variabel independen sebelumnya, pengungkapan tata kelola tidak berpengaruh terhadap Return on Asset. Hasil tidak berpengaruh ini disebabkan kurang menyeluruhnya implementasi praktik good corporate governance. Hasil tidak berpengaruh ini terjadi karena lemahnya praktik good corporate governance dalam perusahaan, sehingga pengungkapan tata kelola bukan 
Pengaruh Pengungkapan ESG Terhadap Kinerja Keuangan Perusahaan

(Studi Empiris Pada Perusahaan Sektor Keuangan Yang Terdaftar Di BEI Periode 2017-2019)

merupakan faktor utama yang mempengaruhi Return on Asset. Di indonesia sebagian besar struktur kepemilikan dalam perusahaan masih didominasi oleh kepemilikan keluarga yang cenderung menghindari penerapan good corporate governace, karena penerapan good corporate governance sendiri akan mengurangi kontrol dari pemegang saham

\section{Pengaruh ESG Terhadap Tobin's $Q$}

Model Regresi 2 menunjukkan bahwa pengungkapan lingkungan tidak berpengaruh terhadap Tobin's Q. Hal ini menunjukkan bahwa shareholder menganggap investasi dalam praktik lingkungan maupun pengungkapannya lebih besar daripada maksimalisasi nilai perusahaan (Buallay, Fadel, Alajmi, \& Saudagaran, 2020). Selain itu pengungkapan lingkungan masih bersifat sukarela, sehingga belum jelas dan masih sulit bagi investor untuk memverifikasinya. Ini sesuai dengan hasil pengujian sebelumnya, bahwa sebesar 90\% faktor yang menjelaskan Tobin's Q adalah faktor dari luar, bukan berasal dari variabel independen sendiri. Pengungkapan sosial juga tidak berpengaruh terhadap Tobin's Q. Perusahaan beranggapan bahwa menetapkan tujuan selain memaksimalkan laba akan menghambat dalam pencapaian pengendali (Wirawan \& Diyanty, 2014). Sehingga hipotesis $\mathrm{H} 1$ yang mengungkapkan bahwa pengungkapan tata kelola berpengaruh positif terhadap Return on Asset ditolak. Hasil penelitian ini sejalan dengan hasil penelitian yang dilakukan oleh (Buallay, Fadel, Alajmi, \& Saudagaran, 2020) dan (Nollet, Filis, \& Mitrokostas, 2016).

competitive sustainability advantage (Jensen, 2017). Sehingga praktik dan pengungkapan sosial bukan merupakan fokus utama untuk meningkatkan nilai perusahaan yang diproksikan oleh Tobin's Q, sebaliknya perusahaan cenderung menggunakan alat lain seperti laba, tingkat likuiditas, dan penjualan sebagai acuan dalam meningkatkan nilai perusahaan (Maama, 2020). Sama dengan kedua variabel sebelumnya, variabel pengungkapan tata kelola juga tidak berpengaruh tehadap Tobin's Q. Ini membuktikan bahwa praktik good corporate governance masih belum berjalan sepenuhnya. Pengungkapan yang dilakukan akan membuat operasional perusahaan menjadi terekspos, dan menjadikan perusahaan lebih diawasi (Christofi, Christofi, \& Sisaye, 2012). Sehingga perusahaan mengungkapkan 
informasi non finansial hanya sebagai bentuk kepatuhan. Kondisi ini bertentangan dengan stakeholder theory bahwa perusahaan harus melakukan pengungkapkan atas informasi non keuangan sebagai bentuk business ethical practice. Sehingga hipotesis $\mathrm{H} 2$ yang menyatakan pengungkapan tata kelola

\section{Pengaruh ESG Terhadap Sales Growth}

Model regresi 3 menunjukkan bahwa pengungkapan lingkungan tidak berpengaruh terhadap Sales Growth. Kondisi ini terjadi karena perusahaan menganggap bahwa praktik dan pengungkapan lingkungan hanya merupakan bagian dari strategi perusahaan, dan belum menerapkannya dalam aktivitas keseharian perusahaan. Selain itu sebagian besar perusahaan berharap imbal balik instan dari praktik dan pengungkapan ESG yang telah dilakukan, sebaliknya business ethical practice seperti ini merupakan proses bertahap yang membutuhkan waktu (Guzman, Castro, \& Torres, 2016). Sehingga dalam penelitian ini pengungkapan lingkungan tidak dapat merefleksikan kinerja keuangan. Pengungkapan sosial juga tidak berpengaruh terhadap Sales Growth. Hasil ini disebabkan oleh informasi sosial yang diungkapkan perusahaan belum layak untuk merefleksikan praktik sosial yang berpengaruh positif terhadap Tobin's Q ditolak. Hasil model regresi 2 sejalan dengan hasil penelitian yang dilakukan oleh (Buallay, Fadel, Al-Ajmi, \& Saudagaran, 2020), (Cornett, Erhemjamts, \& Tehranian, 2016), dan (Fatemi, Glaum, \& Kaiser, 2018).

sebenarnya. Sehingga informasi pengungkapan sosial tersebut tidak berguna bagi investor dalam melakukan penilaian atas praktik dan pengungkapan sosial yang dilakukan oleh perusahaan (Maama \& Appiah, 2019). Pengungkapan tata kelola juga tidak berpengaruh terhadap Sales Growth. Untuk kelompok perusahaan yang masih berpegang padaprinsip tradisional, menganggap bahwa tujuan utama perusahaan adalah memperoleh laba, sedangkan praktik dan atau pengungkapan sosial merupakan bagian dari perusahaan atau organisasi nirlaba. Selain itu sebagian besar perusahaan-perusahaan di sektor keuangan beranggapan bahwa sektor keuangan tidak memberikan dampak negatif secara langsung terhadap lingkungan maupun sosial (Buallay, Fadel, Al-Ajmi, \& Saudagaran, 2020). Sehingga dalam penelitian ini praktik maupun pengungkapan good corporate governance 
Pengaruh Pengungkapan ESG Terhadap Kinerja Keuangan Perusahaan

(Studi Empiris Pada Perusahaan Sektor Keuangan Yang Terdaftar Di BEI Periode 2017-2019)

belum dapat mencerminkan kinerja keuangan yang diproksikan oleh Sales Growth. Hasil penelitian ini bertentangan dengan legitimacy theory tentang perusahaan perlu mempertimbangkan ekspektasi stakeholder, untuk turut bertanggung jawab mengenai isu lingkungan dan sosial, serta menjalankan praktik transparansi dalam tata kelola, dengan tujuan memperkuat

\section{Pengaruh variabel kontrol terhadap} variabel dependen

Dalam model regresi 1 Variabel kontrol ukuran perusahaan memiliki hasil uji berpengaruh dan memiliki hubungan positif terhadap Return on Asset. Artinya semakin besar ukuran perusahaan maka semakin banyak sumber daya yang dapat digunakan untu melakukan praktik pengungkapan ESG, yang dapat meningkatkan Return on Asset perusahaan (Buallay, 2019b). Leverage juga berpengaruh dan memiliki hubungan negatif terhadap Return on Asset. Perusahaan dengan Leverage yang tinggi, cenderung memiliki Return on Asset yang rendah. Kondisi ini terjadi karena perusahaan dengan Leverage tinggi, memiliki kewajiban berupa beban bunga yang tinggi pula, yang akan mengurangi laba (Arifin, Sarita, \& Madi, 2018). Sehingga dari hasil penelitian ini Leverage memiliki hubungan berbanding terbalik dengan Return on Asset. Dalam legitimasinya. Sehingga hipotesis H3 bahwa pengungkapan tata kelola berpengaruh positif terhadap Sales Growth ditolak. Hasil penelitian ini sejalan dengan penelitian (Shahid, Abbas, Latif, Attique, \& Khalid, 2020), (Nyame-Asiamah \& Ghulam, 2019), dan (Plumlee, Brown, Hayes, \& Marshall, 2015).

model 2 variabel kontrol ukuran perusahaan tidak memiliki pengaruh terhadap Tobin's $Q$. Tidak berpengaruhnya ukuran perusahaan terhadap kinerja keuangan dikarenakan ratarata ukuran perusahaan yang diproksikan oleh total aset mengalami peningkatan setiap tahunnya dalam aperiode penelitian 20172019, sedangkan kinerja keuangan yang diproksikan oleh Tobin's $Q$ cenderung fluktuatif. Sehingga dari hasil penelitian ini besar kecilnya ukuran perusahaan belum dapat dijadikan tolak ukur untuk menentukan kinerja keuangan yang diproksikan oleh Tobin's $Q$. Sama halnya dengan ukuran perusahaan, Leverage juga tidak berpengaruh terhadap Tobin's $Q$. Kondisi ini terjadi karena investor tidak mempertimbangkan tingkat Leverage sebagai salah satu faktor acuan untuk menentukan nilai perusahaan (Sofiamira \& 
Haryono, 2017). Pada praktiknya, Leverage lebih sering digunakan untuk menilai kesehatan likuiditas perusahaan, sehingga dari hasil penelitian ini, tinggi rendahnya tingkat Leverage bukanlah kriteria utama yang diperhitungkan oleh investor sebagai penentu nilai perusahaan. Dalam model regresi 3 variabel kontrol ukuran perusahaan berpengaruh negatif terhadap Sales Growth. Perusahaan yang memiliki aset besar belum tentu dapat memanfaatkan aset yang dimilikinya untuk meningkatkan Sales Growth. Semakin besar ukuran perusahaan, maka semakin besar pula pengeluaran yang dibutuhkan untuk kegiatan operasionalnya (Putra \& Badjra, 2015), sehingga terdapat hubungan berbanding terbalik antara ukuran perusahaan dengan Sales Growth. Variabel

\section{SIMPULAN}

Kesimpulan pada penelitian ini adalah, bahwa pengungkapan ESG tidak berpengaruh terhadap kinerja keuangan yang di proksikan oleh Return on Asset, Tobin's Q, dan Sales Growth pada perusahaan - perusahaan di sektor keuangan. Alasan utama dibalik hasil ini adalah perusahaan-perusahaan di sektor keuangan belum memiliki praktik tata kelola perusahaan yang sepenuhnya memahami konsep interdimensional practice, sehingga implementasi business ethical practice seperti kontrol Leverage tidak memiliki pengaruh terhadap Sales Growth. Berdasarkan data sampel kondisi Leverage perusahaan tidak berhubungan dengan keadaan Sales Growth perusahaan. Artinya peningkatan dan atau penurunan Leverage ditujukan untuk maksud lain, peningkatan Leverage dalam perusahaan cenderung digunakan perusahaan untuk memperoleh insentif dalam perpajakan, dan penurunan Leverage ditujukan untuk perbaikan likuiditas perusahaan (Fauziah \& Jamal, 2020). Sehingga dari hasil penelitian ini, keadaan Leverage perusahaan tidak menjadi acuan kondisi Sales Growth perusahaan, hasil penelitian ini sejalan dengan hasil penelitian oleh (Astuti, Wahyudi, \& Mawardi, 2019).

praktik dan pengungkapan ESG belum dilakukan secara layak dan menyeluruh. Saran untuk penelitian selanjutnya adalah menempatkan pengungkapan ESG menjadi variabel dependen, sehingga dapat diketahui faktor-faktor yang mempengaruhi pengungkapan ESG itu sendiri. Serta jumlah sampel yang digunakan sebaiknya dari crossed sector, sehingga hasil penelitian lebih dapat digeneralisasi dengan baik. 


\section{DAFTAR PUSTAKA}

Aboud, A., \& Diab, A. (2018). The impact of social, environmental and corporate governance disclosures on firmvalue: Evidence from Egypt. Journal of Accounting in Emerging Economies, 8(4), $\quad$ 442-458. doi:https://doi.org/10.1108/JAEE-082017-0079

Ahmad, N., Salman, A., \& Shamsi, A. (2015). Impact of Financial Leverage on Firms 'Profitability: An Investigation from Cement Sector of Pakistan. Research Journal Of Finance And Accounting, 6(7), 75-81.

Almajali, A. Y., Alamro, S. A., \& Al-Soub, Y. Z. (2012). Factors Affecting the Financial Performance of Jordanian Insurance Companies Listed at Amman Stock Exchange. Journal of Management Research, 4(2), 266289.

doi:https://doi.org/10.5296/jmr.v4i2.1 482

Ameer, R., \& Othman, R. (2012). Sustainability practices and corporate financial performance: A study based on the top global corporations. Journal of Business Ethics, 108(1), 61-79. doi:https://doi.org/10.1007/s10551-

011-1063-y

Arifin, D. S., Sarita, B., \& Madi, R. A. (2018). Pengaruh Likuiditas, Leverage, Ukuran Perusahaan Dan Pertumbuhan Penjualan Terhadap Profitabilitas (Studi Pada Perusahaan Property dan Real Estate Yang Terdaftar di Bursa Efek Indonesia Tahun 2013-2017). Jurnal Ekonomi Dan Manajemen.

Astuti, F. Y., Wahyudi, S., \& Mawardi, W. (2019). Analysis Of Effect Of Firm Size, Institutional Ownership, Profitability, And Leverage On Firm Value With Corporate Social Responsibility (Csr) Disclosure As Intervening Variables (Study on Banking Companies Listed on BEI Period 2012-2016). Jurnal Bisnis Strategi, $27 \quad$ (2), 95-109. doi:https://doi.org/10.14710/jbs.27.2

Braam, G. J., L, U. D., Hauck, M., \& Huijbregts, M. A. (2016). Determinants of corporate environmental reporting: The importance of environmental performance and assurance. ournal of Cleaner Production, 129, 724-734. doi:https://doi.org/10.1016/j.jclepro.2 016.03 .039 
Buallay, A. (2019a). Is sustainability reporting (ESG) associated with performance? Evidence from the European banking sector. Management of Environmental Quality: An International Journal, $30(1$, 98-115. doi:https://doi.org/10.1108/MEQ-122017-0149

Buallay, A. (2019b). Sustainability reporting and firm's performance: Comparative study between manufacturing and banking sectors. International Journal of Productivity and Performance Management, 69(3), , 431-445. doi:https://doi.org/10.1108/IJPPM10-2018-0371

Buallay, A., Fadel, S. M., Al-Ajmi, J. Y., \& Saudagaran, S. (2020). Sustainability reporting and performance of MENA banks: is there a trade-off? Measuring Business Excellence, 24(2), 197-221. doi:https://doi.org/10.1108/MBE-092018-0078

Buallay, A., Fadel, S. M., Alajmi, J., \& Saudagaran, S. (2020). Sustainability reporting and bank performance after financial crisis: Evidence from developed and developing countries. Competitiveness Review. doi:https://doi.org/10.1108/CR-04-

\section{9-0040}

Christofi, A., Christofi, P., \& Sisaye, S. (2012). Corporate sustainability: Historical development and reporting practices. Management Research Review, 35(2), 157-172. doi:https://doi.org/10.1108/01409171 211195170

Climent, F. (2018). Ethical versus conventional banking: A case study. Sustainability (Switzerland),10(7). doi: https://doi.org/10.3390/su10072152 Cornett, M. M., Erhemjamts, O., \& Tehranian, H. (2016). Greed or good deeds: An examination of the relation between corporate social responsibility and the financial performance of U.S. commercial banks around the financial crisis. Journal of Banking and Finance, $\quad 70, \quad 137-159$. doi:https://doi.org/10.1016/j.jbankfin. 2016.04.024

Dowling, J., \& Pfeffer, J. (1975). Pacific Sociological Association Organizational Legitimacy: Social Values and Organizational Behavior. The Pacific Sociological Review, 18(1), 122-136.

Eccles, R. G., Krzus, M. P., \& Ribot, S. (2015). Models of Best Practice in 
Pengaruh Pengungkapan ESG Terhadap Kinerja Keuangan Perusahaan

(Studi Empiris Pada Perusahaan Sektor Keuangan Yang Terdaftar Di BEI Periode 2017-2019)

Integrated Reporting 2015. ournal of Applied Corporate Finance, 27(2), $103-115$.

doi:https://doi.org/10.1111/jacf.12123

Fatemi, A., Glaum, M., \& Kaiser, S. (2018).

ESG performance and firm value: The moderating role of disclosure. Global

Finance Journal, 38, 45-64. doi:https://doi.org/10.1016/j.gfj.2017. 03.001

Fauziah, F., \& Jamal, S. W. (2020). Analisis Pengaruh Leverage, Financial Performance Firm Size Dan Sales Growth Terhadap Firm Value Pada Perusahaan ... RJABM (Research Journal of ..., 4(2),, 125-146.

Ferrero-Ferrero, I., Izqueirdo-Fernandez, M,

A., \& Munoz-Torres, M. J. (2016).

The effect of environmental, social and governance consistency on economic results. Sustainability (Switzerland), $\quad$ 8(10). doi:https://doi.org/10.3390/su810100 5

Freeman, R. E., \& McVea, J. (1984). A Stakeholder Approach to Strategic Management. SSRN Electronic Journal, January. doi:https://doi.org/10.2139/ssrn.2635 11

Ghozali, I. (2016). Aplikasi Analisis
Multivariate (8th ed., pp. 1-441). Diponegoro: Badan Penerbit Universitas Diponegoro.

Guzman, G. M., Castro, S. Y., \& Torres, G. C. (2016). Corporate Social Responsibility and Business Performance: The Role of Mexican SMEs. International Journal of Asian Social Science, 6(10), 568-579. doi:https://doi.org/10.18488/journal.1 /2016.6.10/1.10.568.579

Harsh, P. S., \& Kumar, S. (2017). Working Capital Requirements of Manufacturing SMEs:. Evidence from Emerging Economy., 1-27. doi:https://doi.org/https://doi.org/10.1 108/RIBS-03-2017-0027

Jensen, M. C. (2017). Value maximisation, Stakeholder theory and the corporate objective function. Unfolding Stakeholder Thinking: Theory, Responsibility and Engagement, 01, $65-84$ doi:https://doi.org/10.2307/3857812

Kocmanova, A., Docekalova, M., Nemecek, P., \& Simberova, I. (2011). Sustainability: Environmental, social and corporate governance performance in Czech SMEs. WMSCI 2011. The 15th World MultiConference on Systemics, Cybernetics 
and Informatics, Proceedings, (pp. 94-99). Czech.

Maama, H. (2020). Institutional environment and environmental, social and governance accounting among banks in West Africa. Meditari Accountancy Research. doi:https://doi.org/10.1108/MEDAR02-2020-0770

Maama, H., \& Appiah, K. O. (2019). Green accounting practices: lesson from an emerging economy. Qualitative Research in Financial Markets, 11(4), 456-478.

doi:https://doi.org/10.1108/QRFM02-2017-0013

Masood, O., \& Ashraf, M. (2012). Bankspecific and macroeconomic profitability determinants of Islamic banks: The case of different countries. Qualitative Research in Financial Markets, 4(2-3), 255-268. doi:https://doi.org/10.1108/17554171 211252565

Melinda, A., \& Wardhani, R. (2020). The Effect of Environmental, Social, Governance, and Controversies on Firms'. Value: Evidence from Asia 27, 147-173.

doi:https://doi.org/10.1108/s1571038620200000027011
Mgbame, C. O., Aderin, A., Ohalehi, P., \& Chijoke-Mgbame, A. M. (2020). Achieving sustainability through environmental social governance reporting: Overcoming the challenges. Advances in Environmental Accounting and Management, 9, 9-25. doi:https://doi.org/10.1108/S1479359820200000009002

Mitnick, B. M. (1975). The theory of agency The policing "paradox" and regulatory behavior. Public Choice, 24(1), 27-42. doi:https://doi.org/10.1007/BF017184 13

Nahavandi, S. (2019). Industry 5.0-a humancentric solution. Sustainability (Switzerland), 11(16). doi:https://doi.org/10.3390/su111643 71

Nawangsari, F. Y., \& Iswajuni, I. (2019). The effects of auditor switching towards abnormal return in manufacturing company. Asian Journal of Accounting Research, 4(1), 157-168. doi:https://doi.org/10.1108/ajar-052019-0040

Nollet, J., Filis, G., \& Mitrokostas, E. (2016). Corporate social responsibility and financial performance: A non-linear and disaggregated approach. Economic Modelling, 52,, 400 - 407. 
Pengaruh Pengungkapan ESG Terhadap Kinerja Keuangan Perusahaan

(Studi Empiris Pada Perusahaan Sektor Keuangan Yang Terdaftar Di BEI Periode 2017-2019)

doi:https://doi.org/10.1016/j.econmod 2015.09.019

Nyame-Asiamah, F., \& Ghulam, S. (2019).

The relationship between CSR activity and sales growth in the UK retailing sector. Social Responsibility Journal, 16(3), 387-401. doi:https://doi.org/10.1108/SRJ-092018-0245

Plumlee, M., Brown, D., Hayes, R. M., \& Marshall, R. S. (2015). Voluntary environmental disclosure quality and firm value: Further evidence. Journal of Accounting and Public Policy, $34(4)$, 336-361. doi:https://doi.org/10.1016/j.jaccpubp ol.2015.04.004

Putra, A., \& Badjra, I. (2015). Pengaruh Leverage, Pertumbuhan Penjualan Dan Ukuran Perusahaan Terhadap Profitabilitas. E-Jurnal Manajemen Universitas Udayana, 4(7), 249411.

Romi, A., Cook, K. A., \& Dixon-Fowler, H. R. (2018). The influence of social responsibility on employee productivity and sales growth: Evidence from certified B corps.

Sustainability

Accounting,Management and Policy

Journal, 9(4), 392-421. doi:https://doi.org/10.1108/SAMPJ-
12-2016-0097

Shahid, M. N., Abbas, A., Latif, K., Attique, A., \& Khalid, S. (2020). The mediating role of board size, philanthropy and working capital management between basic corporate governance factors and firm's performance. Journal of Asian Business and Economic Studies, 27(2), $135-151$.

doi:https://doi.org/10.1108/jabes-072018-0050

Shakil, M. H., Mahmood, N., Tasnia, M., \& Munim, Z. H. (2019). Do environmental, social and governance performance affect the financial performance of banks? A crosscountry study of emerging market banks? Management of Environmental Quality: An International Journal, 30(6), 1331-1344. doi:https://doi.org/10.1108/MEQ-082018-0155

Sofiamira, N. A., \& Haryono, N. A. (2017). Capital Expenditure, Leverage, Good Corporate Governance, Corporate Social Responsibility: Pengaruhnya Terhadap Nilai Perusahaan. Jurnal Ekonomi Dan Bisnis, 20(2), 191. doi:https://doi.org/10.24914/jeb.v20i2 .691 
Statistics, C. B. (2019). Badan Pusat Statistik. From www.bps.go.id: https://www.bps.go.id/publication/20 18/12/07/d8cbb5465bd1d3138 c21fc80/statistik-lingkungan- hidupindonesia-2018.html

Sum, V. (2014). Dynamic effect of Tobin's Q on price-to-earnings ratio. Managerial Finance, $\quad 40(6), \quad 634-643$. doi:https://doi.org/10.1108/MF-072013-0193

Whitelock, V. G. (2015). Relationship between Environmental Social Governance (ESG) Management and Performance - The Role of Collaboration in the Supply Chain. In ProQuest LLC (2017). Ohio: The University of Toledo.

Wirawan, B., \& Diyanty, V. (2014). Kepemilikan keluarga, hubungan politik dan family aligned board terhadap implementasi tata kelola perusahaan. Jurnal Akuntansi \& Auditing Indonesia, 18(2), 139-155. doi:https://doi.org/10.20885/jaai.vol1 8.iss2.art5
Wulf, I., Niemoller, J., \& Rentzsch, N. (2014). Development toward integrated reporting, and its impact on corporate governance: a two-dimensional approach to accounting with reference to the German two-tier system. Journal of Management Control, 25(2), 135-164. doi:https://doi.org/10.1007/s00187014-0200-z

Yawika, M. K., \& Handayani, S. (2019). The Effect of ESG Performance on Economic Performance in the High Profile Industry in Indonesia. Journal of International Business and Economics, $\quad 7(2), \quad 112-121$. doi:https://doi.org/10.15640/jibe.v7n2 a12

Yoon, B., Lee, J. H., \& Byun, R. (2018). Does ESG performance enhance firm value? Evidence from Korea. Sustainability (Switzerland), 10(10). doi:https://doi.org/10.3390/su101036 35 